\title{
Cardiac troponin in ischemic cardiomyocytes: Intracellular decrease before onset of cell death
}

Citation for published version (APA):

Streng, A. S., Jacobs, L. H. J., Schwenk, R. W., Cardinaels, E. P. M., Meex, S. J. R., Glatz, J. F. C., Wodzig, W. K. W. H., \& van Dieijen-Visser, M. P. (2014). Cardiac troponin in ischemic cardiomyocytes: Intracellular decrease before onset of cell death. Experimental and Molecular Pathology, 96(3), 339-345. https://doi.org/10.1016/j.yexmp.2014.02.012

Document status and date:

Published: 01/06/2014

DOI:

10.1016/j.yexmp.2014.02.012

Document Version:

Publisher's PDF, also known as Version of record

Document license:

Taverne

Please check the document version of this publication:

- A submitted manuscript is the version of the article upon submission and before peer-review. There can be important differences between the submitted version and the official published version of record.

People interested in the research are advised to contact the author for the final version of the publication, or visit the DOI to the publisher's website.

- The final author version and the galley proof are versions of the publication after peer review.

- The final published version features the final layout of the paper including the volume, issue and page numbers.

Link to publication

\footnotetext{
General rights rights.

- You may freely distribute the URL identifying the publication in the public portal. please follow below link for the End User Agreement:

www.umlib.nl/taverne-license

Take down policy

If you believe that this document breaches copyright please contact us at:

repository@maastrichtuniversity.nl

providing details and we will investigate your claim.
}

Copyright and moral rights for the publications made accessible in the public portal are retained by the authors and/or other copyright owners and it is a condition of accessing publications that users recognise and abide by the legal requirements associated with these

- Users may download and print one copy of any publication from the public portal for the purpose of private study or research.

- You may not further distribute the material or use it for any profit-making activity or commercial gain

If the publication is distributed under the terms of Article $25 \mathrm{fa}$ of the Dutch Copyright Act, indicated by the "Taverne" license above, 


\title{
Cardiac troponin in ischemic cardiomyocytes: Intracellular decrease before onset of cell death
}

\author{
Alexander S. Streng ${ }^{\mathrm{a}, 1}$, Leo H.J. Jacobs ${ }^{\mathrm{a}, 1,2}$, Robert W. Schwenk ${ }^{\mathrm{b}, 3}$, Eline P.M. Cardinaels ${ }^{\mathrm{a}}$, \\ Steven J.R. Meex ${ }^{\text {a }}$, Jan F.C. Glatz ${ }^{\text {, }}$, Will K.W.H. Wodzig ${ }^{a}$, Marja P. van Dieijen-Visser ${ }^{\text {a,* }}$ \\ a Department of Clinical Chemistry, Maastricht University Medical Centre, Maastricht, The Netherlands \\ b Department of Molecular Genetics and Cardiovascular Research Institute Maastricht, Maastricht University, Maastricht, The Netherlands
}

\section{A R T I C L E I N F O}

\section{Article history:}

Received 17 December 2013

and in revised form 11 February 2014

Available online 4 March 2014

\section{Keywords:}

Cardiac troponin T

Cardiac troponin I

HL-1 cardiomyocytes

Cardiac ischemia

Cell death

\begin{abstract}
A B S T R A C T
Aim: Cardiac troponin I (cTnI) and T (cTnT) are the most important biomarkers in the diagnosis of acute myocardial infarction (AMI). Nevertheless, they can be elevated in the absence of AMI. It is unclear if such elevations represent irreversible cardiomyocyte-damage or leakage from viable cardiomyocytes. Our objective is to evaluate whether cTn is released from viable cardiomyocytes in response to ischemia and to identify differences in the release of cTn and its molecular forms.

Methods and results: HL-1 cardiomyocytes (mouse) were subjected to ischemia (modeled by anoxia with glucose deprivation). The total contents and molecular forms of cTn were determined in culture media and cell lysates. Cell viability was assessed from the release of lactate dehydrogenase (LDH). Before the release of LDH, the intracellular cTn content in ischemic cells decreased significantly compared to control (52\% for cTnI; $23 \%$ for cTnT) and was not matched by a cTn increase in the medium. cTnI decreased more rapidly than cTnT, resulting in an intracellular cTnT/cTnI ratio of 25.5 after $24 \mathrm{~h}$ of ischemia. Western blots revealed changes in the relative amounts of fragmented cTnI and cTnT in ischemic cells.

Conclusions: HL-1 cardiomyocytes subjected to simulated ischemia released cTnI and cTnT only in combination with the release of LDH. We find no evidence of cTn release from viable cardiomyocytes, but did observe a significant decrease in cTn content, before the onset of cell death. Intracellular decrease of cTn in viable cardiomyocytes can have important consequences for the interpretation of cTn values in clinical practice.
\end{abstract}

(c) 2014 Elsevier Inc. All rights reserved.

\section{Introduction}

The cardiac troponin (cTn) complex is a heteromeric protein complex playing an important role in the regulation of cardiac muscle contraction and consists of three different subunits: cardiac troponin I (cTnI), T (cTnT) and C (cTnC). The cTn T-I-C-complex is predominantly structurally bound to the myofibrils with only a minor fraction of cTnT and $\mathrm{cTnI}(6-8 \%)$ present free and unbound in the cytoplasm as soluble intact protein (Bleier et al., 1998; Katus et al., 1991). Due to their cardiac specificity, cTnI and cTnT are accurate and sensitive markers of cardiac

Abbreviations: AMI, acute myocardial infarction; cTnI, cardiac troponin I; cTnT, cardiac troponin T; DMEM, Dulbecco's modified eagle medium; LDH, lactate dehydrogenase; $\mathrm{mAb}$, monoclonal antibody; PBS, phosphate buffered saline.

* Corresponding author at: Department of Clinical Chemistry, Maastricht University Medical Centre, P. Debyelaan 25, P.O. Box 5800, 6202 AZ Maastricht, The Netherlands. Fax: + 31433874692

E-mail address: mp.van.dieijen.visser@mumc.nl (M.P. van Dieijen-Visser).

1 These authors contributed equally.

2 Present working address: Department of Clinical Chemistry and Hematology, Jeroen Bosch Hospital, 's Hertogenbosch, The Netherlands.

${ }^{3}$ Present working address: German Institute of Human Nutrition, Potsdam, Germany. injury and the most important biochemical markers used in the diagnosis of acute myocardial infarction (AMI) (Morrow et al., 2007). Nevertheless, the cardiac troponins (cTns) have been reported to be elevated in the absence of AMI, in situations where irreversible cardiomyocyte damage is unlikely to play an important role (Hamm et al., 2002; Kelley et al., 2009), such as seen in subjects after strenuous exercise (Fortescue et al., 2007; Michielsen et al., 2008; Mingels et al., 2009).

It has been hypothesized that the elevated levels of cTn seen after exercise are the result of a transient increase in the cardiomyocyte membrane permeability, resulting in the release of cTn from the cytosolic cTn pool of cardiomyocytes (Neumayr et al., 2002, 2005; Remppis et al., 1995; Shave et al., 2007). In contrast, irreversible cellular damage, as observed after AMI or myocardial ischemia, will result in the release of both cytosolic and structurally bound cTn (and its complexes) from disintegrating myofibrils. AMI patients undergoing rapid reperfusion demonstrate a first cTnT peak concentration within $24 \mathrm{~h}$ after onset of symptoms, which has been attributed to the fast release of cytosolic cTnT (Bleier et al., 1998; Wu et al., 1998). This peak is followed by a second and persistent CTnT elevation which remains present for 7-14 days and is generally thought to represent the 
relatively slow dissociation of cTnT from the sarcomeres and release from the cells during necrosis. This biphasic release pattern has not been shown for cTnI, which release is characterized by an initial rise, directly followed by a gradual decrease to undetectable levels.

In addition to different release kinetics between cardiomyocytes with increased membrane permeability (reversible damage) and irreversible damage, there may also be a difference in released molecular forms of cTn. The cTns are thought to be targets for proteases such as caspase (Communal et al., 2002; Lancel et al., 2005) and calpain (Barta et al., 2005; Ke et al., 2008; Kositprapa et al., 2000), which are being activated and released during cell-death. Therefore, $\mathrm{cTn}$ is expected to be released partly fragmented from irreversibly damaged cells, whereas cytosolic cTn released after reversible damage will be predominantly intact. Moreover, the complexed (myofibril bound) forms of cTn might be more susceptible to proteolytic degradation than the free forms, as illustrated by Communal et al., who found that caspase- 3 cleaves cTnT when it is in complex with cTnI and cTnC, but not as free cTnT (Communal et al., 2002).

Hessel et al. showed the release of intact cTnI from viable cardiomyocytes by stimulation of stretch-responsive integrins (Hessel et al., 2008a), a model in which irreversible damage is unlikely to occur. Conversely, irreversible cardiomyocyte damage, induced by metabolic inhibition with sodium azide, induced the simultaneous release of intact and fragmented forms of both cTnI and cTnT (Hessel et al., 2008a,b; Li et al., 2004). In a recent study, Cardinaels et al. clearly showed time-related degradation of cTnT after myocardial infarction (Cardinaels et al., 2013). Intact cTnT rapidly disappears from the serum after the ischemic event and progressively smaller cTnT fragments appear in time. Degradation and changes in the molecular forms of cTn may have consequences for the immunoreactivity of the antibodies used in the various clinical assays. Assays based on different antibodies may therefore generate different results when measuring cTn concentrations in the same serum sample, which complicates the clinical interpretation of those measurements.

In this in vitro study we investigated the release kinetics of cTn and its molecular fragments in cell culture using true conditions of ischemia. This was achieved by subjecting HL- 1 cardiomyocytes to a complete anoxic environment with glucose deprivation. The HL-1 atrial cardiomyocyte cell line can contract in solution, maintains a differentiated adult cardiac phenotype up to at least 240 passages and can be recovered from frozen stocks (Claycomb et al., 1998). The aims of our study are, firstly, to investigate whether cTn can be released from ischemic, but viable, cardiomyocytes and secondly, to analyze the molecular forms of the cTns released from cells subjected to ischemia.

\section{Methods}

\section{Cell culture of HL-1 atrial cardiomyocytes}

HL-1 cardiomyocytes (derived from an AT-1 mouse atrial cardiomyocyte tumor lineage) were kindly provided by Dr. W. Claycomb (Louisiana State University, New Orleans, LA, USA), and cultured as described previously (Claycomb et al., 1998; Schwenk et al., 2010). Briefly, the cells were grown in Claycomb medium (Claycomb et al., 1998) supplemented with 10\% Fetal Bovine Serum (FBS), $0.1 \mathrm{mM}$ norepinephrine, $2 \mathrm{mM}$ L-glutamine, $100 \mathrm{U} / \mathrm{mL}$ penicillin and $100 \mu \mathrm{g} / \mathrm{mL}$ streptomycin at $37{ }^{\circ} \mathrm{C}$ and at an atmosphere of $5 \% \mathrm{CO}_{2}$ and $95 \%$ air. For routine passaging, the cells were maintained in T-75 flasks and split twice a week after reaching confluence. For each of our experimental conditions the cells were seeded onto 6 -well culture plates at a density of 100,000 cells $/ \mathrm{cm}^{2}$ and grown for $24 \mathrm{~h}$ in supplemented Claycomb medium prior to the experimental treatment. The same batch of cells was used for all time points and for both the anoxia and control experiments. The medium used for the experimental treatment of the HL-1 cells consisted of Dulbecco's modified eagle medium (DMEM), supplemented with $2 \mathrm{mM}$ L-glutamine, $100 \mu \mathrm{M}$ non-essential amino-acids (NEAA), 0.5\% albumin,
$100 \mathrm{U} / \mathrm{mL}$ penicillin, $100 \mu \mathrm{g} / \mathrm{mL}$ streptomycin; with or without $4.5 \mathrm{~g} / \mathrm{L}$ glucose.

Ischemia was modeled by anoxia and glucose deprivation. At the start of our experiment $(t=0)$, Claycomb medium was replaced with supplemented DMEM without glucose and the cells were immediately placed in an anoxic environment (MACS VA500 microaerophilic workstation, Don Whitley Scientific, Shipley, UK). The atmosphere in the chamber consisted of $5 \% \mathrm{CO}_{2}, 5 \% \mathrm{H}_{2}$ and residual $\mathrm{N}_{2}$. Anoxia treatment is performed for 1, 3, 5, 7, 9, 12 and $24 \mathrm{~h}$.

As a control, non-treated HL-1 cells grown for 0, 1, 3, 5, 7, 9, 12 and $24 \mathrm{~h}$ in supplemented DMEM with glucose were grown alongside the ischemic cells. Fig. 1 depicts the workflow used in the cell culture experiments from routine cell passaging to the storage of individual medium and lysate samples.

\section{Sample collection and cTn measurements}

After each treatment period, the culture medium was collected and centrifuged for $5 \mathrm{~min}$ at $500 \mathrm{RCF}$ and the supernatant was stored at $-80{ }^{\circ} \mathrm{C}$. Immediately after medium removal the cells were washed twice with cold $\left(4^{\circ} \mathrm{C}\right)$ phosphate buffered saline (PBS) and $600 \mu \mathrm{L}$ cold $\left(4{ }^{\circ} \mathrm{C}\right)$ RIPA lysis buffer, containing $150 \mathrm{mM} \mathrm{NaCl}, 50 \mathrm{mM}$ Tris- $\mathrm{HCl}, 1 \%$ (v/v) Igepal CA-630, 0.5\% (w/v) sodium deoxycholate, 0.1\% (w/v) SDS, and $4 \%(\mathrm{v} / \mathrm{v})$ complete protease inhibitor cocktail and $5 \%$ (v/v) PhosSTOP phosphatase inhibitor cocktail was added to each well. The cells were lysed for $2 \mathrm{~h}$ with mild agitation at $4{ }^{\circ} \mathrm{C}$. Resulting cell lysates were stored at $-80{ }^{\circ} \mathrm{C}$ until analysis.

Troponin concentrations were measured in DMEM and RIPA buffer aliquots. cTnT concentrations were measured using the 4th generation cTnT immunoassay on the Elecsys 2010 instrument (Roche Diagnostics, Mannheim, Germany), with a limit of detection (LOD) of $<0.01 \mu \mathrm{g} / \mathrm{L}$, a $10 \% \mathrm{CV}$ of $0.03 \mu \mathrm{g} / \mathrm{L}$ and a linear measuring range of $0.010-25.00 \mu \mathrm{g} / \mathrm{L}$, according to the product insert. cTnI concentrations were measured using the AxSYM ${ }^{\circledR}$ Troponin-I ADV assay (Abbott Diagnostics, Wiesbaden, Germany), with an LOD of $0.02 \mu \mathrm{g} / \mathrm{L}$, a $10 \% \mathrm{CV}$ of $0.16 \mu \mathrm{g} / \mathrm{L}$ and a linear measuring range of $0.02-22.78 \mu \mathrm{g} / \mathrm{L}$.

\section{Cell death}

The release of lactate dehydrogenase (LDH) into the culture medium was used to quantify cell death. The cytosolic protein LDH is released from cells exhibiting a loss of membrane integrity as seen during primary and secondary necrosis and its release is commonly used to quantify cell-death (Hessel et al., 2008b; Seymour et al., 2003). LDH activity was determined with the LD-P lactate dehydrogenase assay on the Synchon LX20 pro clinical system (Beckman Coulter Inc., Palo Alto, CA, USA), with a linear measuring range of $20-2500 \mathrm{IU} / \mathrm{L}$ and a $5.3 \% \mathrm{CV}$ of $22.5 \mathrm{IU} / \mathrm{L}$. The release of $\mathrm{LDH}$ is expressed as the $\mathrm{LDH}$ activity in the culture medium as a percentage of the total LDH in the well:

$$
\mathrm{LDH}_{\text {medium }} /\left(\mathrm{LDH}_{\text {medium }}+\mathrm{LDH}_{\text {lysates }}\right) * 100 \%
$$

In addition to the LDH release, the amount of viable cells was also estimated by measuring the total protein content in the collected cell lysates with the BCA (bicinchoninic acid) Protein Assay Reagent (Thermo Fisher Scientific, Inc., MA, USA), according to the manufacturer's instructions.

\section{Validation of protein measurements}

The clinical assays used to measure protein concentrations are optimized for the use in human serum. In order to exclude any matrixeffects from influencing our measurements, we validated their use in DMEM and RIPA buffer. Fig. 2 shows LDH (a), cTnI (b) and cTnT (c) concentration curves of untreated cell lysates serially diluted in either 


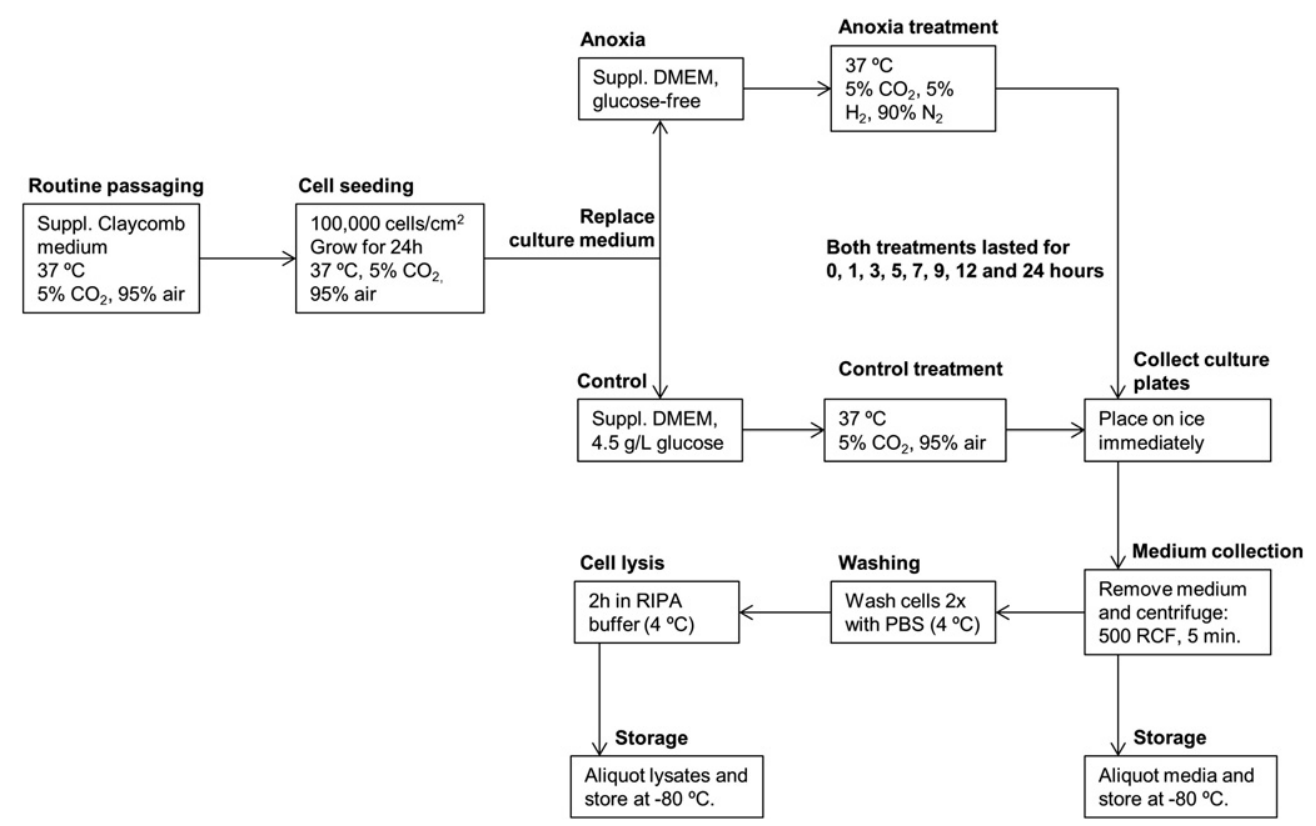

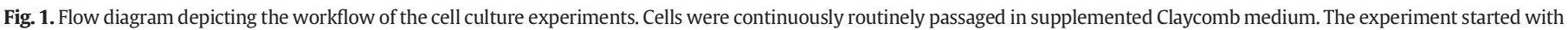

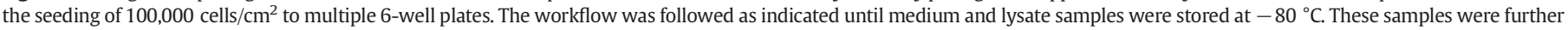
processed as described in the method section.

DMEM or RIPA buffer. From the figure follows that the LDH, cTnI and cTnT assays used in this study give linear results over their entire measuring ranges in our used buffers and that the DMEM and RIPA curves are superimposed, indicating that measurements in both buffers are comparable to one another. Samples with concentrations outside of this range were diluted 10 times in the appropriate buffer before measurement. The Roche cTnT immunoassay shows a slight increase in measured cTnT concentration in the medium as compared to the RIPA buffer, resulting in a measurement that is on average $14 \%$ higher in the medium (Fig. 2c).

\section{Detection of cTnI and cTnT degradation products}

Before protein separation, the cell lysate samples were diluted to a cTnI concentration of $1 \mu \mathrm{g} / \mathrm{L}$ or to a cTnT concentration of $7.5 \mu \mathrm{g} / \mathrm{L}$ (unless stated otherwise). The cell culture lysates were each mixed with $4 \times \mathrm{XT}$ Sample Buffer (Bio-Rad, 161-0791) and 20× Reducing Agent (Bio-Rad, 161-0792) and heated for $5 \mathrm{~min}$ at $95^{\circ} \mathrm{C}$. Subsequently, $25 \mu \mathrm{L}$ of the samples, containing equal amounts of $\mathrm{cTnT}$ and $\mathrm{cTnI}$, was separated on a $12 \%$ Criterion XT SDS-PAGE gel (Bio-Rad, 345-0118). Proteins were then transferred to a nitrocellulose membrane (Bio-Rad, 162-0115, $0.45 \mu \mathrm{m}$ ). Further treatment of the blots was done with the SNAP i.d. protein detection system (Millipore) according to the manufacturer's instructions. Briefly, blocking was performed for $10 \mathrm{~s}$ with $0.5 \%(\mathrm{w} / \mathrm{v})$ Blocking buffer (Bio-Rad, 170-6404). The incubation with the primary antibody (specified below) was performed for $10 \mathrm{~min}$. After washing (washed $4 \times$ with PBS with $0.1 \%(\mathrm{v} / \mathrm{v})$ Tween-20 (PBST)), the blot was incubated with secondary antibody (specified below) and washed $4 \times$ with PBST. The following primary and secondary antibodies were used:

All primary antibodies were mouse monoclonal antibodies (mAbs) ordered from HyTest LTD, Turku, Finland. For cTnT the primary anticTnT solution was a mixture of the following mAbs: 9G6 (epitope: 160), 1c11 (epitope: 171-190), 7F4 (epitope: 67-86), and 7A9 (epitope: 171-190) at concentrations of $2 \mu \mathrm{g} / \mathrm{mL}$. For cTnI, the primary anti-cTnI was a mixture of 3 anti-cTnI mAbs: $19 C 7$ (epitope: 41-49), MF4 (epitope: 190-196) and 84 (epitope: 117-126) at concentrations of $4 \mu \mathrm{g} / \mathrm{mL}$. The secondary antibody solution consisted of $0.4 \mu \mathrm{g} / \mathrm{mL}$ goat anti-mouse $\operatorname{IgG}$ conjugated with peroxidase (Dako, P0447) in PBST. Membranes were incubated for $5 \mathrm{~min}$ in Super Signal West Femto Substrate (Thermo
Scientific, 34096) and exposure was detected using the ChemiDoc XRS scanner (Bio-Rad).

\section{Data analysis and statistics}

Experiments were performed in triplicate and data are presented as mean $+/-$ S.E.M. Comparisons are made with using Student's paired t-test with $\mathrm{p}<0.05$ considered statistically significant. Protein release (for CTnI, cTnT and LDH) is defined as the percentage of total protein that is present in the medium: Release $=[\mathrm{Pm}] /[\mathrm{Pm}+\mathrm{Pl}] * 100 \%$; $\mathrm{Pm}=$ protein amount in the medium and $\mathrm{Pl}$ is the protein amount in the cell lysate. The recovery of each of the proteins is defined as the amount of protein that can be recovered at each time point, relative to the amount in the control: $\left(\right.$ Recovery $\left.=[\mathrm{Pl}+\mathrm{Pm}]_{\text {experimental }}\right) /$ $\left([\mathrm{Pl}+\mathrm{Pm}]_{\text {control }}\right) * 100 \%$. The relative amount of intact and fragmented cTnI and cTnT was determined by densitometry, using the Quantity One software (Bio-Rad, Version 4.6.5.).

\section{Results}

\section{Protein release after ischemic damage}

Cell viability was assessed by measuring the release of LDH into the medium. In response to ischemia, LDH is gradually being released into the culture medium starting between 3 and 5 h of treatment (Fig. 3a and b). During this period, intracellular cTnI and cTnT contents decreased by $52 \pm 7 \%$ and $23 \pm 7 \%$, respectively, compared to control (Fig. 3c). This intracellular decrease was not matched by an increase in the medium (Fig. 3d). We were only able to detect cTn in the medium after the release of $\mathrm{LDH}$. This means that there is a considerable loss in the total amount of cTn, illustrated by a recovery decrease during the first $3 \mathrm{~h}$ of treatment (Fig. 3e). The slight increase in protein recoveries after $24 \mathrm{~h}$ is most likely caused by a decrease of the net cellular protein content in the control cells (Fig. 3a and c) due to substrate depletion of the culture medium. Throughout the treatment, all of the LDH could be recovered (average recovery: $107 \pm 5 \%$ ). As an alternative measure of cell viability, the total protein content of the cell lysates was assessed and showed an excellent correlation with the LDH content (Spearman's rho $=0.843, \mathrm{p}<0.001 ;$ results not shown). 

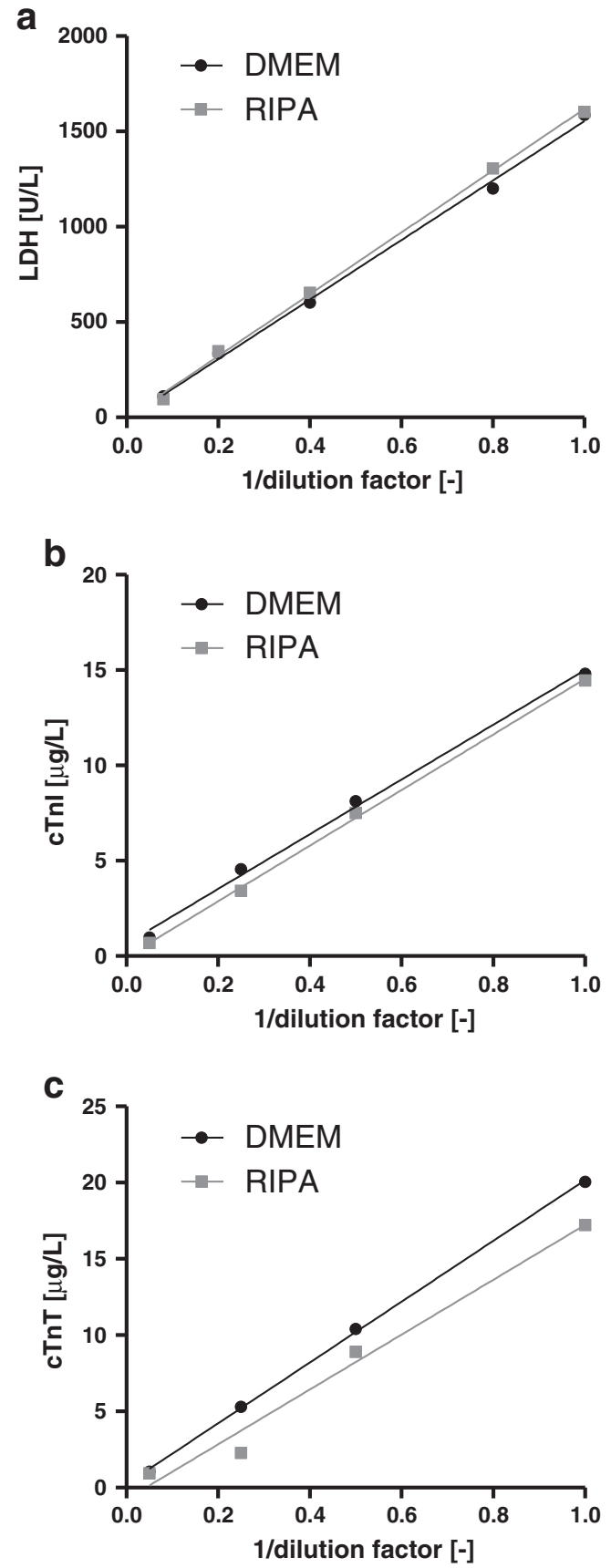

Fig. 2. Validation of the clinical assays for measuring protein concentrations in DMEM and RIPA buffer spiked with untreated cell lysates. a. LDH measurements in DMEM $\left(r^{2}=0.997\right)$ and RIPA buffer $\left(r^{2}=0.999\right)$ using the LD-P assay by Beckman Coulter. b. cTnI measurements in DMEM $\left(r^{2}=0.996\right)$ and RIPA buffer $\left(r^{2}=0.999\right)$ using the Troponin-I ADV assay by Abbott. c. cTnT measurements in DMEM $\left(r^{2}=1.000\right)$ and RIPA buffer $\left(r^{2}=0.981\right)$ using the 4 th generation cTnT assay by Roche.

cTnI seems to be released earlier than cTnT and follows the same release curve as LDH. After $5 \mathrm{~h}$ of treatment approximately $68 \pm 12 \%$ of the measurable cTnI is released into the medium compared to only $18 \pm 5 \%$ for cTnT (Fig. 3f). In addition to the slower release of cTnT, the maximum cTnT release is also lower than that of cTnI ( 79 vs $94 \%$, respectively). This suggests that cTnT remains in the cell lysates longer than cTnI. After $24 \mathrm{~h}$ of treatment, the ratio between cTnT and cTnI in the cell lysates increased to $25.5( \pm 1.8)$ in the $24 \mathrm{~h}$ ischemiatreated cells compared to $1.58( \pm 0.13)$ in the control, as measured by the clinical assays employed in this study (Fig. 4).

\section{Increase in troponin fragmentation upon ischemia}

Western blots of the cell lysates were performed to investigate whether a change in the molecular forms of cTn could be found. A mixture of different mAbs was used to create optimal coverage of both proteins. The results show two separate bands for cTnI: intact cTnI migrating to $29 \mathrm{kDa}$ and a cTnI fragment migrating to $25 \mathrm{kDa}$ (Fig. $5 \mathrm{a}$ ). About $91 \%$ of the total signal on this blot originates from the $29 \mathrm{kDa}$ band and $9 \%$ from the $25 \mathrm{kDa}$ band. After $5 \mathrm{~h}$ of anoxia the relative intensities of the bands began to change with increasing lengths of treatment. After $12 \mathrm{~h}$, the relative signal of the $25 \mathrm{kDa}$ band had increased to $34 \%$ and the $29 \mathrm{kDa}$ band decreased to $66 \%$. After $24 \mathrm{~h}$, cTnI content has dropped to a level where it was no longer possible for them to be visualized.

For cTnT, a similar effect was seen, although less pronounced. In the control samples and during the first hours of ischemia, 98-99\% of the total signal originated from the $37 \mathrm{kDa}$ (intact $\mathrm{cTnT}$ ) band (Fig. 5b). Upon progressive lengths of ischemia, the relative amount of the $37 \mathrm{kDa}$ band decreased and a cTnT fragment band at $27 \mathrm{kDa}$ started appearing. After $24 \mathrm{~h}$ the intensity of the fragment band increased to 7.4\% and the intact cTnT band decreased accordingly.

Western blots from the culture media were also performed, however, no fragmentation was observed and only a very feint, single, intact, cTnI and cTnT band was visible throughout the experiment (results not shown).

\section{Discussion}

In this study, we explored the release of cTnT and cTnI in an in vitro model in which HL-1 cardiomyocytes were subjected to ischemia and glucose deprivation. cTnI and cTnT were being released from the cardiomyocytes starting between 3 and $5 \mathrm{~h}$ after the initiation of treatment. This release was associated with a concomitant release of LDH, implying that the release of troponin only occurred after the onset of cell-death. No cTn release was observed during the first $3 \mathrm{~h}$. Interestingly, we did observe a significant decrease of the cTnI and cTnT contents (52\% and 23\%, respectively) during this period which was not matched by an increase in the medium and was more pronounced for cTnI than for cTnT.

The release characteristics of cTnI and cTnT from the cells in response to ischemia seemed comparable to those seen after AMI. Following an AMI, the cTnI and cTnT concentrations begin to rise 3-6 h after the onset of AMI and peak after 12-24 h (Collinson, 1998; Januzzi, 2011). Similarly, the HL-1 cells began releasing cTnI and cTnT between 3 and $5 \mathrm{~h}$ of ischemia. Within our model, we found a more pronounced increase in cTnI medium levels in the early hours after the onset of ischemia than for CTnT (Fig. 3d and f). cTnI was released alongside LDH, while cTnT release appears to occur 1 or $2 \mathrm{~h}$ later. A possible explanation for this could lie in the fact that cTnI is located outermost on the thin filament (Toyo-Oka and Ross, 1981), which may facilitate a more readily access to proteases such as caspase (Communal et al., 2002) and calpain (Barta et al., 2005; Ke et al., 2008; Kositprapa et al., 2000), whereas cTnT is structurally bound to tropomyosin with high affinity (Feng et al., 2009; Perry, 1998).

In the case of LDH, every decrease in the lysates resulted in an increase in the medium. In the end, an average of $107 \pm 5 \%$ of total LDH was recovered. However, before the cTns were released into the medium, a significant decrease in their cellular contents was detected. This decrease was not matched by an increase in the medium and is not observed in control cells. We have not been able to explain this decrease, but an analytical effect is unlikely. In this report, the presented data was not corrected for matrix effects of the assays. Even though a slight measurement difference between culture medium and lysis buffer was shown for the Roche cTnT assay (Fig. 2c), correcting for this deviation would reduce the recovery of cTnT even further (61\% recovery instead of $67 \%$ after $24 \mathrm{~h}$ of treatment, results not shown). Several explanations can be offered for this seemingly selective decrease in troponin content. The 

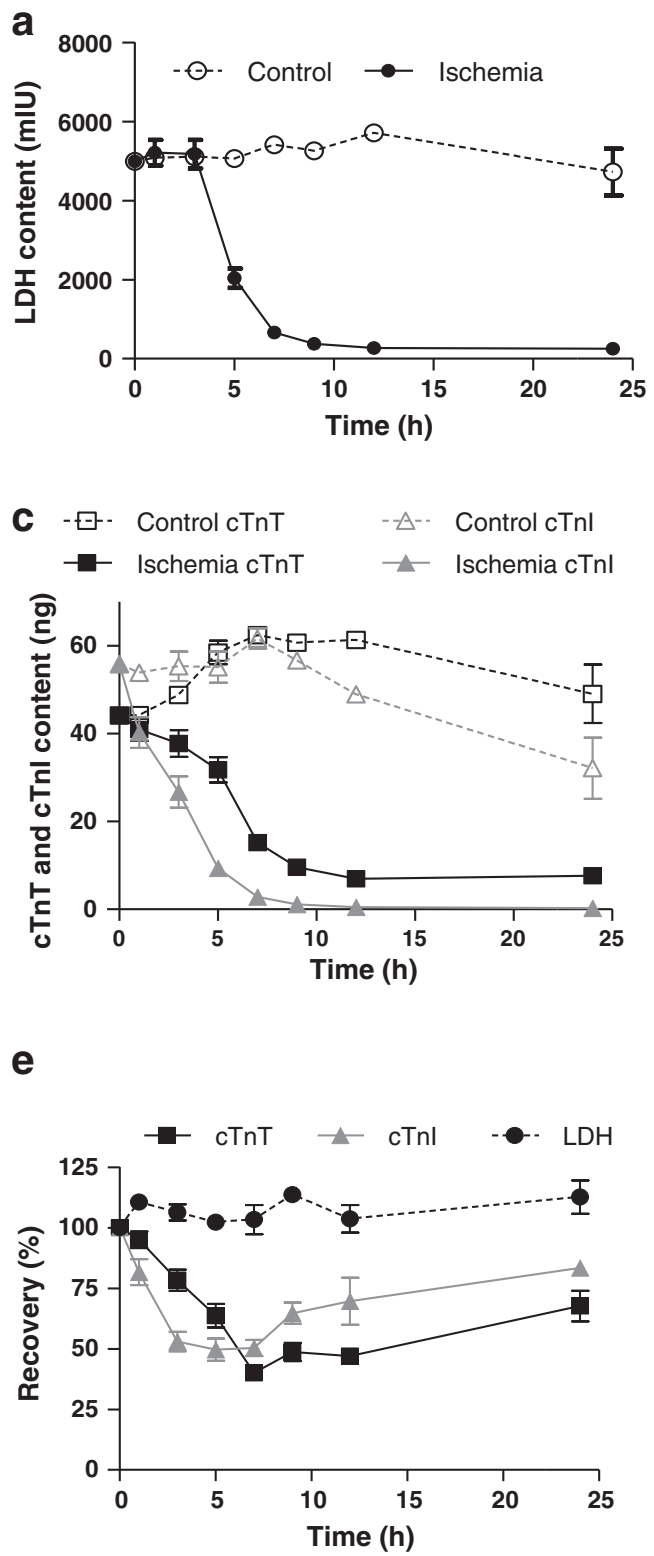

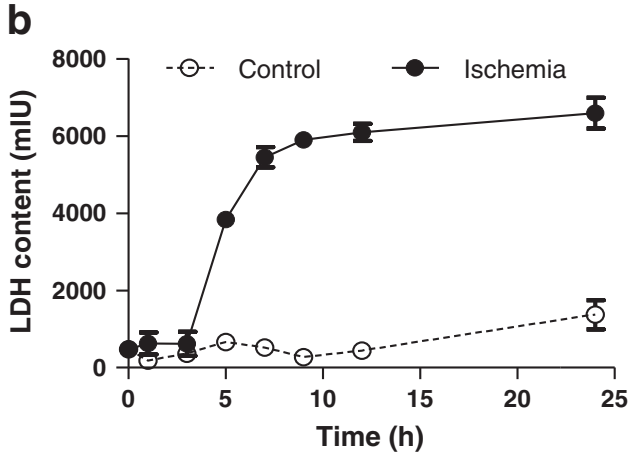

d

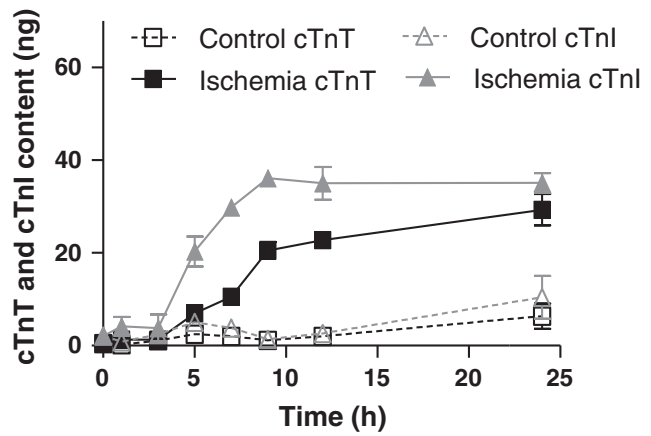

f

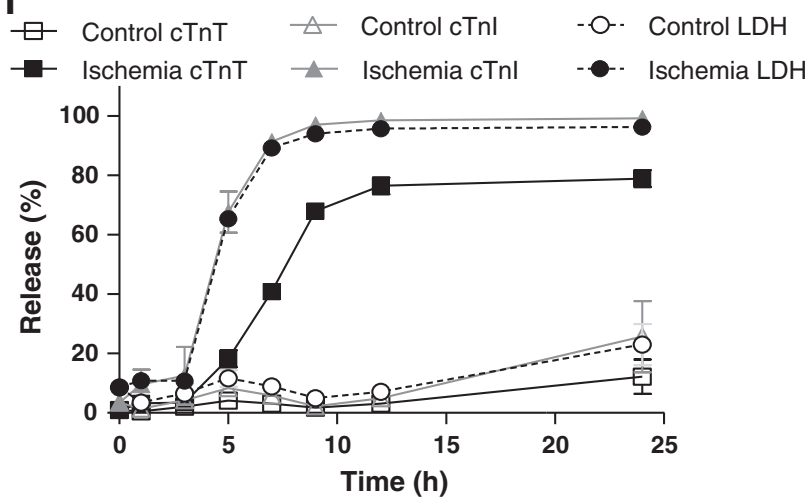

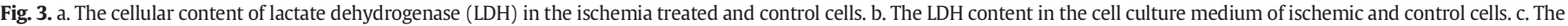

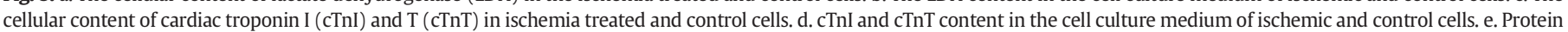

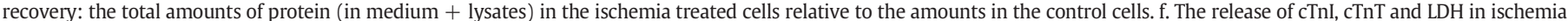
treated and control cells. The release is expressed as the amount in the culture medium as a percentage of the total amount in the well.

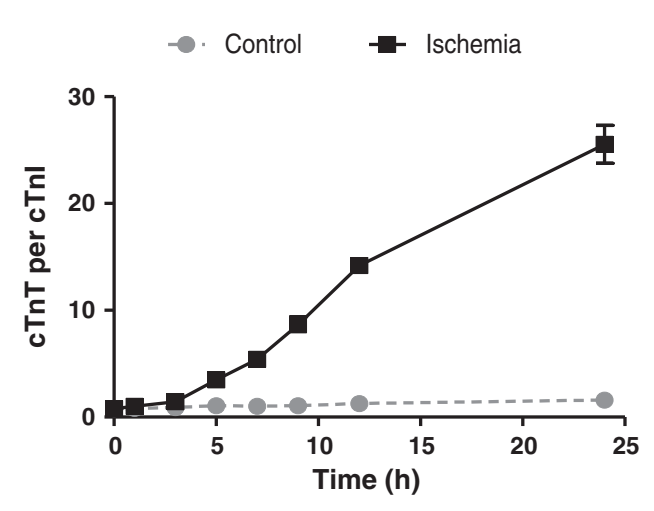

Fig. 4. Intracellular $\mathrm{cTnT} / \mathrm{cTnI}$ ratio of ischemic and control cells as a function of treatment time, as measured with the clinical cTn assays by Roche diagnostics (cTnT) and Abbott diagnostics (cTnI). most prominent one is the complete degradation of these proteins by the proteasome in a process called autophagy. Autophagy pathways are highly upregulated in cardiomyocytes upon ischemia as part of a cardioprotective mechanism (Sciarretta et al., 2013). This mechanism reduces necrosis and apoptosis and could therefore explain why our cells are able to survive for a seemingly long period without glucose and oxygen. The intracellular degradation of troponin is further shown by western blots of cTnI and cTnT which showed an increase in degradation products in response to the ischemia treatment. In addition, the decreased measured concentration might also be the result of other (specific or non-specific) modifications, such as phosphorylation (Layland et al., 2005; Streng et al., 2013) and ubiquitination (Kedar et al., 2004; Witt et al., 2005), which might have an influence on antibody affinity. Irrespective of the exact underlying mechanism for the intracellular decrease, the decreased recoveries suggest that the released cTns represent only a relatively small part of the total amount of cTn that was originally present in the cardiomyocytes. This finding is a 
a

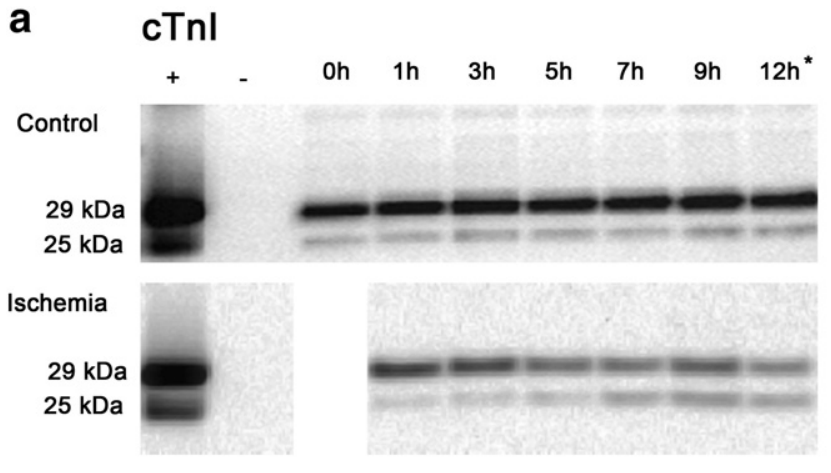

b

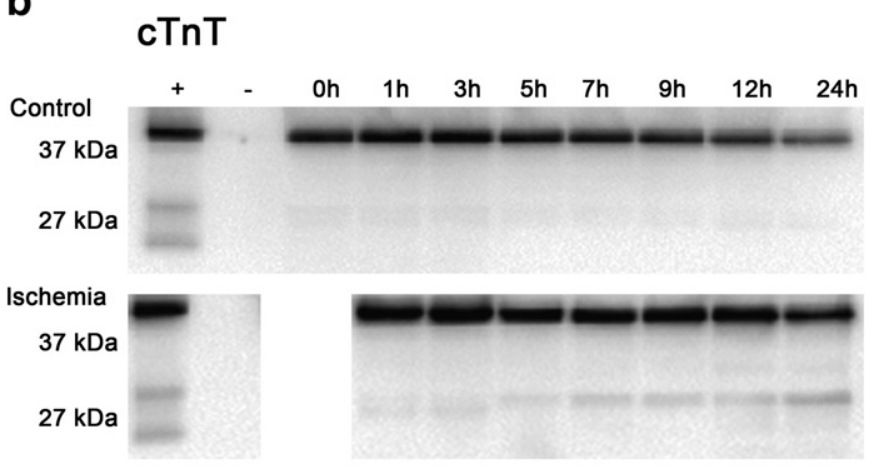

๑. $29 \mathrm{kDa}$ Control -๘. $25 \mathrm{kDa}$ Control

$\rightarrow 29 \mathrm{kDa}$ Ischemia $\rightarrow 25 \mathrm{kDa}$ Ischemia

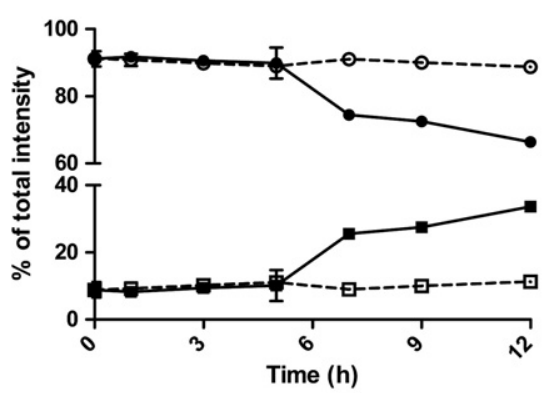

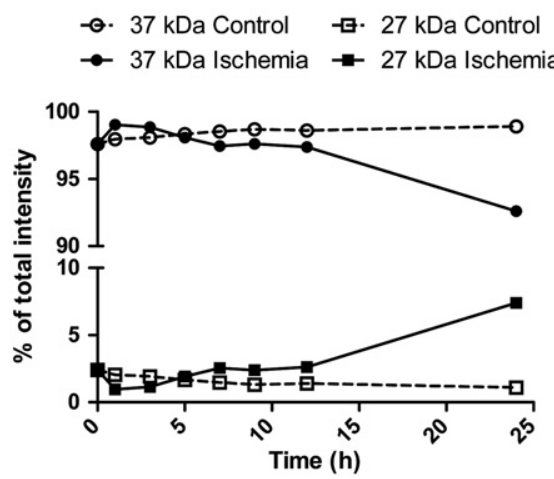

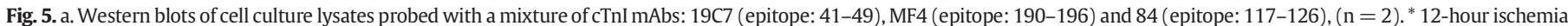

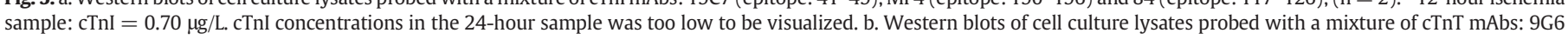
(epitope: 1-60), 1C11 (epitope: 171-190), 7F4 (epitope: 67-86) and 7A9 (epitope: 171-190).

confirmation of a study with neonatal rat cardiomyocytes by Hessel et al. In that study, recoveries of $34 \%$ for $\mathrm{cTnI}$ and $39 \%$ for cTnT were found in response to $24 \mathrm{~h}$ of metabolic inhibition using sodium azide (Hessel et al., 2008b). More importantly, this phenomenon might also occur in vivo, where the reduced recoveries may be even more pronounced. Early reports have shown that at $72 \mathrm{~h}$ after AMI only 4-5\% of cTnT is recovered (in comparison to cytoplasmic enzymes like LDH) (Kragten et al., 1996).

In this study, we used an immortalized atrial cardiomyocyte cell line. By using these cells, we were able to perform a multitude of experiments to validate and fine-tune our model. Our results have been very reproducible and treatment and control conditions could be carefully controlled. However, we recognize that primary cardiomyocytes would have resembled the in vivo situation more closely and that our cells are atrial instead of ventricular. On the other hand, HL-1 cardiomyocytes are well defined and extensively characterized. They have been used in numerous studies since their creation and have been shown to resemble primary cardiomyocytes very closely (White et al., 2004). Despite these limitations, the implications of molecular changes on the immunoreactivity of cTn in the clinical immunoassays should not be underestimated. Results from our study suggest that in vivo, only part of the released cTn is measured in the serum. Future experiments need to be performed to unravel the precise mechanisms behind this "disappearance" of cTn from viable cardiomyocytes.

\section{Funding}

This work was supported by the E.C. Noyons Foundation for the Advancement of Clinical Chemistry in The Netherlands and by a research grant from Stichting De Weijerhorst.

\section{Conflict of interest statement}

The authors declare that they have no conflict of interest.

\section{Acknowledgments}

The authors are grateful to Kevin Gerritsen for valuable experimental contributions and to Dr. Douwe de Boer for insightful discussions.

\section{References}

Barta, J., Toth, A., Edes, I., Vaszily, M., Papp, J.G., Varro, A., et al., 2005. Calpain-1-sensitive myofibrillar proteins of the human myocardium. Mol. Cell. Biochem. 278, 1-8.

Bleier, J., Vorderwinkler, K.P., Falkensammer, J., Mair, P., Dapunt, O., Puschendorf, B., et al., 1998. Different intracellular compartmentations of cardiac troponins and myosin heavy chains: a causal connection to their different early release after myocardial damage. Clin. Chem. 44, 1912-1918.

Cardinaels, E.P., Mingels, A.M., van Rooij, T., Collinson, P.O., Prinzen, F.W., van Dieijen-Visser M.P., 2013. Time-dependent degradation pattern of cardiac troponin T following myocardial infarction. Clin. Chem. 59, 1083-1090.

Claycomb, W.C., Lanson Jr., N.A., Stallworth, B.S., Egeland, D.B., Delcarpio, J.B., Bahinski, A., et al., 1998. HL-1 cells: a cardiac muscle cell line that contracts and retains phenotypic characteristics of the adult cardiomyocyte. Proc. Natl. Acad. Sci. U. S. A. 95, 2979-2984.

Collinson, P.O., 1998. Troponin T or troponin I or CK-MB (or none?). Eur. Heart J. 19 (Suppl. N), N16-N24.

Communal, C., Sumandea, M., de Tombe, P., Narula, J., Solaro, R.J., Hajjar, R.J., 2002. Functional consequences of caspase activation in cardiac myocytes. Proc. Natl. Acad. Sci. U. S. A. 99, 6252-6256.

Feng, H.Z., Hossain, M.M., Huang, X.P., Jin, J.P., 2009. Myofilament incorporation determines the stoichiometry of troponin I in transgenic expression and the rescue of a null mutation. Arch. Biochem. Biophys. 487, 36-41.

Fortescue, E.B., Shin, A.Y., Greenes, D.S., Mannix, R.C., Agarwal, S., Feldman, B.J., et al., 2007. Cardiac troponin increases among runners in the Boston Marathon. Ann. Emerg. Med. 49, 137-143 (43 e1).

Hamm, C.W., Giannitsis, E., Katus, H.A., 2002. Cardiac troponin elevations in patients without acute coronary syndrome. Circulation 106, 2871-2872. 
Hessel, M.H., Atsma, D.E., van der Valk, E.J., Bax, W.H., Schalij, M.J., van der Laarse, A 2008a. Release of cardiac troponin I from viable cardiomyocytes is mediated by integrin stimulation. Pflugers Arch. 455, 979-986.

Hessel, M.H., Michielsen, E.C., Atsma, D.E., Schalij, M.J., van der Valk, E.J., Bax, W.H., et al. 2008b. Release kinetics of intact and degraded troponin I and T after irreversible cell damage. Exp. Mol. Pathol. 85, 90-95.

Januzzi, J.L., 2011. Cardiac Biomarkers in Clinical Practice. Jones and Bartlett Publishers, Sudbury, Mass.

Katus, H.A., Remppis, A., Scheffold, T., Diederich, K.W., Kuebler, W., 1991. Intracellular compartmentation of cardiac troponin $\mathrm{T}$ and its release kinetics in patients with reperfused and nonreperfused myocardial infarction. Am. J. Cardiol. 67, 1360-1367.

Ke, L., Qi, X.Y., Dijkhuis, A.J., Chartier, D., Nattel, S., Henning, R.H., et al., 2008. Calpain mediates cardiac troponin degradation and contractile dysfunction in atrial fibrillation. J. Mol. Cell. Cardiol. 45, 685-693.

Kedar, V., McDonough, H., Arya, R., Li, H.H., Rockman, H.A., Patterson, C., 2004 Muscle-specific RING finger 1 is a bona fide ubiquitin ligase that degrades cardiac troponin I. Proc. Natl. Acad. Sci. U. S. A. 101, 18135-18140.

Kelley, W.E., Januzzi, J.L., Christenson, R.H., 2009. Increases of cardiac troponin in conditions other than acute coronary syndrome and heart failure. Clin. Chem. 55, 2098-2112.

Kositprapa, C., Zhang, B., Berger, S., Canty Jr., J.M., Lee, T.C., 2000. Calpain-mediated proteolytic cleavage of troponin I induced by hypoxia or metabolic inhibition in cultured neonatal cardiomyocytes. Mol. Cell. Biochem. 214, 47-55.

Kragten, J.A., Hermens, W.T., van Dieijen-Visser, M.P., 1996. Cardiac troponin T release into plasma after acute myocardial infarction: only fractional recovery compared with enzymes. Ann. Clin. Biochem. 33 (Pt 4), 314-323.

Lancel, S., Joulin, O., Favory, R., Goossens, J.F., Kluza, J., Chopin, C., et al., 2005. Ventricular myocyte caspases are directly responsible for endotoxin-induced cardiac dysfunction. Circulation 111, 2596-2604.

Layland, J., Solaro, R.J., Shah, A.M., 2005. Regulation of cardiac contractile function by troponin I phosphorylation. Cardiovasc. Res. 66, 12-21.

Li, L., Hessel, M., van der Valk, L., Bax, M., van der Linden, I., van der Laarse, A., 2004. Partial and delayed release of troponin-I compared with the release of lactate dehydrogenase from necrotic cardiomyocytes. Pflugers Arch. 448, 146-152.

Michielsen, E.C., Wodzig, W.K., Van Dieijen-Visser, M.P., 2008. Cardiac troponin T release after prolonged strenuous exercise. Sports Med. 38, 425-435.

Mingels, A., Jacobs, L., Michielsen, E., Swaanenburg, J., Wodzig, W., van Dieijen-Visser, M. 2009. Reference population and marathon runner sera assessed by highly sensitive cardiac troponin T and commercial cardiac troponin T and I assays. Clin. Chem. 55, 101-108.

Morrow, D.A., Cannon, C.P., Jesse, R.L., Newby, L.K., Ravkilde, J., Storrow, A.B., et al., 2007. National academy of clinical biochemistry laboratory medicine practice guidelines: clinical characteristics and utilization of biochemical markers in acute coronary syndromes. Circulation 115, e356-e375.

Neumayr, G., Pfister, R., Mitterbauer, G., Maurer, A., Gaenzer, H., Sturm, W., et al., 2002. Effect of the "race across the alps" in elite cyclists on plasma cardiac troponins I and T. Am. J. Cardiol. 89, 484-486.

Neumayr, G., Pfister, R., Mitterbauer, G., Eibl, G., Hoertnagl, H., 2005. Effect of competitive marathon cycling on plasma N-terminal pro-brain natriuretic peptide and cardiac troponin T in healthy recreational cyclists. Am. J. Cardiol. 96, 732-735.

Perry, S.V., 1998. Troponin T: genetics, properties and function. J. Muscle Res. Cell Motil. 19, 575-602.

Remppis, A., Scheffold, T., Greten, J., Haass, M., Greten, T., Kubler, W., et al., 1995. Intracellular compartmentation of troponin $\mathrm{T}$ : release kinetics after global ischemia and calcium paradox in the isolated perfused rat heart. J. Mol. Cell. Cardiol. 27, 793-803.

Schwenk, R.W. Dirkx, E., Coumans, W.A, Bonen, A, Klip, A, Glatz, J.F., et al, 2010. Requirement for distinct vesicle-associated membrane proteins in insulin- and AMP-activated protein kinase (AMPK)-induced translocation of GLUT4 and CD36 in cultured cardiomyocytes. Diabetologia 53, 2209-2219.

Sciarretta, S., Yee, D., Shenoy, V., Nagarajan, N., Sadoshima, J., 2013 Nov 14. The importance of autophagy in cardioprotection. High Blood Press. Cardiovasc. Prev. [Epub ahead of print].

Seymour, E.M., Wu, S.Y, Kovach, M.A, Romano, M.A. Traynor, J.R., Claycomb, W.C, et al, 2003. HL-1 myocytes exhibit PKC and K(ATP) channel-dependent delta opioid preconditioning. J. Surg. Res. 114, 187-194.

Shave, R., George, K., Gaze, D., 2007. The influence of exercise upon cardiac biomarkers: a practical guide for clinicians and scientists. Curr. Med. Chem. 14, 1427-1436.

Streng, A.S., de Boer, D., van der Velden, J., van Dieijen-Visser, M.P., Wodzig, W.K., 2013. Posttranslational modifications of cardiac troponin T: an overview. J. Mol. Cell. Cardiol. 63, 47-56.

Toyo-Oka, T., Ross Jr., J., 1981. Ca ${ }^{2+}$ sensitivity change and troponin loss in cardiac natural actomyosin after coronary occlusion. Am. J. Physiol. 240, H704-H708.

White, S.M., Constantin, P.E., Claycomb, W.C., 2004. Cardiac physiology at the cellular level: use of cultured HL-1 cardiomyocytes for studies of cardiac muscle cell structure and function. Am. J. Physiol. Heart Circ. Physiol. 286, H823-H829.

Witt, S.H., Granzier, H., Witt, C.C., Labeit, S., 2005. MURF-1 and MURF-2 target a specific subset of myofibrillar proteins redundantly: towards understanding MURF-dependent muscle ubiquitination. J. Mol. Biol. 350, 713-722.

Wu, A.H., Feng, Y.J., Moore, R., Apple, F.S., McPherson, P.H., Buechler, K.F., et al., 1998. Characterization of cardiac troponin subunit release into serum after acute myocardial infarction and comparison of assays for troponin $\mathrm{T}$ and $\mathrm{I}$. American Association for Clinical Chemistry Subcommittee on cTnI Standardization. Clin. Chem. 44, 1198-1208. 